\title{
Power Relation Between Local Bossism and Local Actor in Management of Forestry Sector in Muna Regency
}

\author{
Aenal Fuad Adam ${ }^{1}$, Laode Machdani Afala ${ }^{2}$ \\ $\left\{\right.$ aenal.fuadadam@gmail.com $\left.{ }^{1}\right\}$ \\ Universitas Haluoleo \\ Universitas Brawijaya ${ }^{2}$
}

\begin{abstract}
Local bosses and local elite are the main actors who determine how local government is governed at a local level. Democracy and decentralization policies in post-New Order have opened a chance for their presence in local politics. This paper explains power relations between local bosses (Ridwan BAE, Muna Regent) and local actors at local legislative, forestry office, and another local government agency in the management of forestry sector in Muna Regency. This paper is a study case using a qualitative approach. In analyzing data the research uses some concepts of bossism, patronage, and clientelism. The paper concludes that the local boss exploited the forestry sector particularly the teak forest as a political instrument to build patronage and clientelism networks to local actors in Muna Regency. The networks of power relation are political and forcing in which local boss uses the networks in order to maintain the power and to gain economic interest.
\end{abstract}

Keywords: Local Bossism, local elite, Forestry Sector, Patronage, Clientelism

\section{Introduction}

International In the modern political landscape, local politics is not only governed by formal actors but also by non-formal actors. Their presence in local politics comes along with the wave of democratization and decentralization occurred in almost all of the states around the world. In Indonesian local politics, the presence of the non-informal actors has increasingly emerged in the post-New Order Regime [1]. This paper reveals the economicpolitical networks shaped by non-formal and formal actors, particularly in a relationship between local boss and local actor in the management of the forestry sector, especially in case of teak forest in Muna Regency. Apparently, the new policies in local politics are not aimed to increase local government revenue (PAD) and to perform good governance, but in contrast, as a battlefield for formal and non-formal actors in seizing the power and gaining their economic interest. In this paper, the local actors are the elites in local government agencies (SKPD) and local businessmen in Muna Regency, while the local boss was the Muna Regent, Ridwan BAE, who ruled as long two periods from 2000 to 2010.

Since the implementation of decentralization policy, changes in the political system and the configuration of local politics after the authoritarian regime (New Order regime) have affected the governance of local economic resources in Indonesia. The first is the decentralization policy through the granting of authority in the management of regional resources to local governments from the central government. With the presence of Law No. 25 
of 1999 concerning the financial balance between the central government and regional governments, the local government has the power to manage regional resources which then become sources of local revenue. It is stated through the rules of state revenue from natural resources divided by a $20 \%$ balance for the central government and $80 \%$ for the local government which in turn becomes the pretext of the authorities in the local using their power and authority to extract natural wealth in the name of development. Second, it is granting central authority to local governments in the management of local development policies. Through the policy of regional autonomy, local government has the legitimacy of power economically and politically to manage the region. With this, many of the authorities on the pretext of local autonomy build and manage their government in order to gain their personal interest.

In studying the local power actors, there are a number of literature that examine the emergence of non-formal actors in the development of democracy at the local level, especially in Indonesia. Through an institutional approach, McCharty explained that the weakness of state institutions had an impact on the presence of social forces that carried out informal economic management practices [2]. The strengthening of personalistic relations and ethnic ties in Central Kalimantan, according to McCarthy, established a commodity link in accessing the benefits of forest management activities. Likewise, with the study conducted by Erman, through the shadow state approach, he explained that the state's political power is institutionalized to the local level, does not affect the presence of non-formal actors in carrying out economic practices and influence the formal political actors [3]. The weak penetration of state power has shrunk state power in conducting political and economic practices at the local level.

Moreover, Syarif Hidayat through the political economy approach explained there has the hijacking of the state committed by local strong people by placing members of his family in the structure of state power [4]. Their goal is to influence the State policy in order to accommodate their business interests. The presence of these powerful local people indirectly sought to monopolize the state's resources. Similar to studies conducted by Sidel, the Mafia, clans, and gangs became non-formal actors who became the local bosses who could influence and control the formal power of the state [5].

If earlier studies explain the weakness of the state giving rise to powerful local actors in local political developments, this paper is basically present to reaffirm the power of the State. The emergence of non-formal actors is regarded as the form of the extension of the power state. Thus, the state is not weak, on the contrary, the phenomenon of the presence of powerful local actors shows the strong penetration of the state power at local politics.

Change in political structure and democratization has led to the rise of local strongmen and local bosses in some Southeast Asian countries. This is also acknowledged by many Indonesian researchers who have devoted much attention to post-reformation and regional autonomy as the entrance to the emergence and enduring power of local bosses at the local level. They have expounded the rise of social forces such as Nobility of Usif in Nusa Tenggara Timur, Karaeng in Makassar, and Sultan in Java as local strongman symbols that are culturally legitimated and able to survive in the socio-political structure at the local level [1]. However, this paper explores the extent to which local boss powers operate in local economic management practices.

Muna Regency is known as one of the largest producers of teak forest in Indonesia. The teak forest is the main commodity growing almost in many areas of Muna island. In 2001, forest area in Muna was at 235.759 hectares or 48,24\% from total area of 488.700 hectares, which consisted of normal production forest with 39.685 hectares $(16,83 \%)$, limited 
production forest with 11.693 hectares (4,95\%), protected forest with 46.363 hectares $(19,67 \%)$, tourism forest with 82.009 hectares, and conversed production forest with $23,76 \%$ [6]. Meanwhile, in 2014 Statistic Board of Muna Regency noted that the forest area has shrunk to be 94.254 hectares or $31.80 \%$ from the total of Muna Land covering normal production forest with 43.104 hectares, limited production forest with 1.472 hectares, protection forest with 30.750 hectares, tourism forest with 9.975 and converted production forest with 8.953 hectares [7].

Tracking from the early Reformation Era of Muna Regency there had been present the figure of local bosses who dominate the socio-political field. Contestation in the local election had given rise to a figure who was a successful businessman in the political field to be an executive leader in Muna Regency named Ridwan BAE (2000-2010). His position as a regent had placed him as a powerful figure in the political field as well as the economic field. He had transformed to be a new local boss in the early Reformation Era. Besides, under his administration, he steered all local government agents in Muna Regency in order to support his own interest, particularly in the management of forestry sector.

In first decentralization introduced across Indonesia, local bosses saw it as an opportunity to manage the forestry sector as an entity with the high economic value that was capable of improving the economy and development. In the decentralization era, the discourse of economic improvement and development was a mission of every local government. In Muna Regency, the management of the forestry sector led to illegal logging activities that occurred in all forest areas. Using his power, the local boss commanded evictions and arrests of local people residing in forestry areas due to accusations of the occupation of State forest lands illegally. This is the way in which local boss forces to control over local people in forest areas. It can be seen as a form of power penetration in regulating society in accordance with his economic interest. The local boss uses state resource to control and accumulate his profit through managing forestry sector.

\subsection{Local Bosses Concept}

Starting from the view of Sidel in his comparative studies in Southeast Asia such as the Philippines, Thailand, and Indonesia, Sidel shows the presence of new social forces that have the structure, character of power, and socio-political base that rely on state power. He shows the phenomenon of bossism or strong local people as an anti-thesis of the Migdal approach that understands local strongman as someone who has undermined local politics in the three countries [5].

The difference between Sidel and Migdal can be seen from their perspective about the relationship between state and society. Migdal is based on the perspective of a society-center in seeing the state as a political order that has been undermined by social forces (strongmen). The local strongmen have network and power in penetrating and using the state. According to him, the political leaders of third world countries have faced obstacles from social forces in society with an interest in state policies. This shows the social-political order dominated by the interests of local strongmen who mobilize their interests through networks of power that have undermined the state.

More clearly, Migdal's perspective sees the decay of state institutions and functions as the main factor causing the emergence of local strongmen [8]. The success of local strongmen is with placing their networks of power in a number of strategic government positions to ensure the allocation of resources that go according to their own rules. More specifically, Migdal's main argument is that (1) the local strongmen thrives in a network-like society as a collection of self-sustaining social organizations that exert influence beyond the influence of local leaders and bureaucrats. (2) local strongmen exercise social control and have the legitimacy 
that places itself as a patron for clients in their territory, and (3) local strongmen succeed in capturing state institutions and state resources that limit the autonomy and capacity of the state, run a goal-oriented social change.

However, in contrast to Sidel's view of trying to criticize the Midgal perspective through a state-centered approach that views the state as not in a weak state. But, Sidel views that the state autonomy and the overwhelming capacity of the state have reflected the ability of state actors to manage their territories. Sidel tries to analyze the emergence of local bosses by pointing out to the change of political structure and political institutionalization into the beginning of the blurring and rooting of local boss power in some countries in Southeast Asia.

In the case of the Philippines, Sidel saw that the phenomena of local bosses emerged along with changes in closed political and electoral structures and their long-standing turnover facilitated local bosses to immerse themselves and to establish monopolistic controls in the local economy for years [9]. Interestingly, Sidel explained the patron-client relationship as a social glue tool that has ignored the force power and monopoly in electoral politics as well as social relations. While in the Thailand case, Sidel sees the same thing in which local bosses in local terminology are called Cao Po, emerge simultaneously with the formation of state and capitalist development through the monopolistic nature of economic activity in the territory of their power derived from the state. Cao Po managed to take root because of serving or voting in the parliamentary elections in Bangkok.

Nevertheless, Indonesia's local boss pattern is different from local boss patterns in the Philippines and Thailand. In Sidel's view, the pattern of local bosses in Indonesia shows a very different pattern that refers to the terminology of the mafia, the network, and the clan. According to Sidel, the change in a political structure marked by the presence of reform and decentralization, along with local elections, is the entrance to the emergence of local bosses in Indonesia by seizing power at the local level in order to occupy the highest positions of local government. In the democratization and decentralization of Indonesia, local bosses have the opportunity to capture state-level positions and state institutions at the local level.

In Sidel's view, Mafia, clan and network groups are alliances and affiliates within the network of clientelism and state patronage. In the New Order Regime, State had limited the emergence of local strongmen and local bosses emerging and rooted throughout the archipelago. Some restrictions on the position and mutation of regional officials conducted by New Order Regime did not allow them to be firmly and permanently rooted in their respective domains. However, Sidel suspects that the emergence of a wave of democratization that hit Indonesia, changes in political structure that coincided with local elections became the entrance to the emergence of local bosses across the archipelago.

More specifically, local bosses come along with democratization and decentralization where the presence of branches of political parties, parliaments at the local level, have strengthened patronage networks in the regions to access public resources and local institutions. In this regard, the local bosses are a reflection of state formation and capitalization development where their presence as a trap of electoral democracy has been formally oppressed by the interests of local bosses over the state as a primitive accumulation stage. In other words, local bosses refer to power brokers who have positions and enduring monopolistic control over the coercive power and economic resources in their respective domains.

\subsection{Actor Resource Concept}

The concept of power becomes important to be used to analyze the resources that local bosses have for exercising their power in Muna County. The conception of power can be understood as the capacity of actors to take action to influence others. As Budiarjo quoted the 
thought of Lasswell and Kaplan that the essence of power is the ability of the individual to influence the actions of other individuals in accordance with the wishes of the individual who has the power [10]. Likewise, "The Encyclopedia Of Political Science" explains that power is an ability that includes the ability to act autonomously, have influence or control over others that are used to achieve the goals and interests of social actors [11]. In addition, power has an instrumental nature depicted in the circumstances of social actors (holders of power) can persuade or force other actors to act in terms of advancing the interests of the authorities [12]. Thus, the conception of power can be understood as a relationship between two or more in which the holder of power exercises control over a number of others.

However, in examining the power of political actors the capacity of a political actor is an important thing. Capacity here can be measured from sources of power such as position, wealth, trust, and skill of social actors. More clearly the capacity can be understood as a form of social actors' ability to use resources in order to obtain compliance from others. According to Adrain, resources are divided into five types of political resources consisting of physical power, economic power, normative power, personal power and expertise power [13].

The types of physical resources in question are such as possession of weapons that have the potential to obtain compliance from others. The possession of weapons can be interpreted as an instrument of power and the capacity of influencing actions which in turn will gain the adherence of others. The type of economic resources can be in the form of wealth, income and ownership of production sources. Through economic resources, actors are able to influence others to gain compliance by providing material rewards to others.

Normative resource types can be interpreted as possessing qualified resources such as religious policy, moral truth, and legitimate authority. The normative resources are a legitimate resource and social actors have the right to exercise power. Relating to this paper, the normative resources for local bosses are based on official positions derived from organizations and countries.

Personal resources can be understood as the ability of a local boss personally seen from his personal abilities such as an attractive, captivating, and charismatic turn. to make others interested and obedient to him. This type of skill resource is understood as the ability of social actors who have capital such as information, knowledge, technical expertise and intelligence [13]. In the exercise of power, social actors must have the knowledge and ability to run state institutions and the ability to organize others.

Skill resources are a picture of the social actors' acumen in acting to exercise their power and influence. Power and type of resources are important in examining the local boss's power base in Muna Regency. Relating to local bosses as local rulers in Muna Regency, the state is seen as a resource of power that can be used for their own interests and ambitions. As Sidel points out, the power base of local bosses relies heavily on the State where the ability to control state institutions, in turn, is conducted by the monopoly of economic activity legally.

\subsection{Patronage and Clientelism Concepts}

Patronage and clientelism are two inseparable sides of the coin where clientelism is known as a patron-client model that influences contemporary political systems around the world. Conceptually, clientelism is another form of patronage practice that is a reciprocal relationship that refers to a complex chain of bonds personal relationship between patrons and clients built on mutually beneficial cooperation [14].

Aspinall \& Sukmajati interpret clientelism as a characteristic of the power relationship between local bosses and other actors who are personalistic, mutually beneficial, contingent, hierarchical and intertwined aspects of repetition [15]. More specifically, as Legg states, the 
clientelist network is present when allied partners control non-comparable resources, personalistic relationships and a mutually beneficial relationship established [16].

Looking at the above explanation can be concluded that clientelism is a form and pattern of relationships between patrons and clients are personalistic, hierarchical and mutual relationships between patrons and clients. In its interaction there is profit sharing between the local boss and the client as well as the client will repay the services of the local boss in return for a mutually beneficial form of cooperation. Thus, clientelism can be seen from (1) the interaction between local bosses and local actors involved in personalistic relationships; (2) local bosses have resources not shared by clients (local actors) that will form an asymmetric relationship; and (3) a relationship of mutual exchange exists between local bosses and clients (local actors) that are mutually beneficial to both parties.

The clientelism concept in this paper is used to understand the patterns and characteristic of relationships that exist between local bosses and local actors in the management of the forestry sector. In this case, local bosses are categorized as patrons while local actors are categorized as clients. Clientelism and patronage politics in practice cannot be separated wherein the work of clientelism, patronage distributed that will be exchanged to the client for political support. When referring to The Encyclopedia Of Political Science (2011) patronage is understood as a practice of using state resources by a ruler or political leader (patron) to provide jobs and services to clients or supporters in order to gain support.

In a similar vein, Muller interprets patronage as the use of public resources that are exchanged to the client or followers to a patron who will get political support such as voting in the election [17]. Thus, patronage refers to the use of public resources that will be exchanged with the client for support. Clientelism is a characteristic of relations and networks formed from a special relationship such as personal relationships, kinship ties, and abilities in which there is a mutually beneficial relationship between the local boss and the client.

\section{Method}

This research uses a qualitative method by using a case study model as a choice of method and strategy in obtaining data. Case study as a research method is defined as a qualitative study that seeks to discover meaning, investigate processes, and gain insight and deep understanding of individuals, groups or social situations [18]. A case study is a more suitable research strategy on how or why questions when researchers have few opportunities to control the events to be investigated in the social settings. In term of the management of forestry sector in Muna Regency, a case study is used to identify and understand the case of how Ridwan BAE emerged and how the power relation and network between Ridwan BAE as local boss and local actors in the management of the forestry sector in Muna Regency shaped.

So that, in case of study method, the researcher collects data from field study and library and then gives explanation, interpretation, and perception of the result of some information and documentation that are obtained from data that have been collected in the field. Furthermore, the data then are generalized into the form of narration which in turn the researcher explains the uniqueness of this study of local actors analyzed. In analyzing data, the research borrows bossism, patronage, and clientelism concepts in which data that have been categorized are analyzed based on those concepts.

\section{Result and Discussion}

\subsection{The Emergence of Local Bosses in Muna Political Structure}


The post-New Order political era becomes the structure of the opportunity of local elites. This era is marked by the presence of election and becomes a political momentum for local bosses for bringing their ambition and self-interest to gain power in their own region. Aryandi reveals that the presence of local bosses is inseparable from the fragility of social, political and economic situations that are happening at the local level [19]. The situation gives rise to the emergence of the new social forces to be able to reposition their political position to a higher level.

In the case of Muna Regency, Ridwan Bae was local boss emerging in the post-New Order regime. He is commonly called La Moho who was born in Muna precisely in the village of Lemoambo on 1st December 1957. He was born in a very simple family of the couple of La Ode Madaidi and Wa Ode Runa. His father was a former village head who was a leadership clan. After earning an architect degree at Hasanuddin University, Ridwan became a businessman and consultant in the pioneering career. Being a consultant has been started since he was a student in University. With both colleagues of Andi Sakka and Kristomus, Ridwan also established a company of CV. Daya Bina. By the company, for the first time, Ridwan was able to gain the trust of local governments in working on the planning projects of the provincial government agencies of Southeast Sulawesi.

Besides, Ridwan is also known as an active person in the organization. In his profession as a consultant, Ridwan was listed as a member of the organization IKINDO (Association of Indonesian Consultants). In IKINDO, Ridwan was elected as General Secretary from 1985 to 1990. His position showed Ridwan's natural talent. Through IKINDO, Ridwan built his networking with government and colleagues in his profession as social capital in his career and business.

Nevertheless, his career with colleagues experienced ups and downs and faced an internal conflict which then forced Ridwan to switch his profession to be a contractor by establishing PT. RAPESA (Rimadu Wuna Persada). By forming his own company, Ridwan's career as a contractor also increased after being elected as the Chairman of HIPMI (Association of Young Entrepreneurs Indonesia) of Southeast Sulawesi Province in 1992 - 1998. Furthermore, in his career as a contractor, Ridwan was elected as Chairman of KADIN (Indonesian Chamber of Commerce and Industry) in Southeast Sulawesi Province from 1994 to 1999.

Ridwan career in the political field cannot be separated from his career as a contractor. Through his company and HIPMI which was an alliance of the New Order power, he set his foot into the political field. His career in business led him to join in organizations which are an affiliate of the Golkar party such as HIPMI, KADIN, IKINDO, and KNPI in Southeast Sulawesi. Through many organization affiliated to Golkar party, the political career of Ridwan arguably run so smooth.

In legislative career, Ridwan was elected by the Muna Regent, Maola Daud, as a member of the local legislative assembly (DPRD) of Muna Regency through the period of KNPI (Indonesia National Youth Committee) period 1992 - 1997. KNPI gave him a seat for it. After that, in 1993 Ridwan served as a member of DPD I Golkar of Southeast Sulawesi who was later elected as Vice Chairman of DPD (Regional Representative Board) Golkar of Sulawesi Southeast. After the collapse of the New Order, Ridwan returned to the national level by registering as a candidate for MPR RI (People Consultative Assembly) representatives of the region.

At that time, the Regent election was still carried out indirectly by regional assembly (DPRD) members in Muna Regency. The election of the Regent was determined by the factions in the DPRD through consultation to the leadership of the Muna regional assembly. Mechanisms such as this provide bargaining power to DPRD elites to lobby and vote. 
Tabel 1. The Number of Seats in Muna Regional Assembly

\begin{tabular}{ll}
\hline Political Party & Seats \\
\hline PDI Perjuangan & 4 \\
PDI & 2 \\
Reformasi & 9 \\
TNI POLRI & 3 \\
Golkar & 16 \\
PPP & 2 \\
PKB & 1 \\
PARI & 1 \\
PBB $\quad$ Total & 1 \\
& 30 \\
\hline
\end{tabular}

Source: Kabupaten Muna dalam Angka 2010

Starting from to secure the interests of the Governor of Southeast Sulawesi in the election, the regent of Muna Ridwan BAE and his colleagues were assigned to smooth the interests of the Governor to pass Lasjkar Koedoes as a Regent candidate from the Golkar faction. However, in reality Ridwan BAE chose a political attitude and declared himself as a Bupati candidate through the Golkar Faction. Interestingly, Ridwan BAE was one of the contractors and entrepreneurs who were very close in the circle of power of the Governor of Southeast Sulawesi. However, in reality Ridwan BAE openly opposed the interests of the "patron" of the Governor of Southeast Sulawesi.

The action taken by Ridwan BAE was a political calculation with rational action based on the increasingly loose political situation after the reform. As revealed by Aryandi, it led to the emergence of new social forces to try to reposition their status and political position towards a higher level in Muna Regency [19]. Changing political structures and the limited nature of the state gave birth to an opportunity structure which in turn gave rise to local bosses at the local level. Although Ridwan BAE faced obstacles in the selection of candidates in the Golkar Party, through lobbying and facilitation payments Ridwan BAE was able to win the most votes and be entitled to become regent candidates from the Golkar faction.

The contest of the regent election was finally followed by Ridwan BAE - Syarif AS, Lasjkar Koedoes - La Ode Hayamudi and Laode Sefu - La Ode Malik Nditu, in which there were 30 members of Muna regional assembly (DPRD). In first round, the election of regents by DPRD members was a tough one where Ridwan BAE-Syarif AS obtained 15 votes, Lasjkar Koedoes-Hayamudi obtained 11 votes, and Malik Nditu-La Ode Sefu obtained 4 votes. The second round was won by Ridwan BAE-Syarif AS with 17 votes, while Lasjkar KoedoesHayamudi won 13 votes. The victory of Ridwan BAE-Syarif AS was indicated by the smell of conspiracy through political transactions with several regional assembly (DPRD) members. Thanks to his expertise, Ridwan BAE was able to win the most votes through political clicks with several members of the regional assembly (DPRD).

3.2 Seizing Power in Muna Regency

Starting from the political stance of Ridwan BAE as a regent, who opposed the Governor and chairman of Golkar DPD at the time, he declared himself as a new boss in Muna Regency. The declaration became a boomerang for Governor where Ridwan BAE was early known as his follower. Viewed from the relationship between Ridwan BAE and the Governor can be said there was resistance to the patron at the provincial level. This indicates that the political dynamics in Muna Regency seem to be more fluid due to changes in the political structure at the local level post-New Order regime. 
The changing of political structure and the nature of the limited state has created an opportunity structure for the emergence of a local boss in Muna Regency. In addition, this is also due to a transition that is characterized by economic turmoil and political fragmentation at the local level which then presents a structure of political opportunity for elites to seize and compete for power. The change in political structure will then become an opportunity structure for Ridwan BAE to form new rules, strengthen his capital and network of power. All of it is an effort to be able to preserve and maintain his power in Muna Regency. Nordholt said that the fall of Soeharto's regime, local bureaucrats, and party bosses will reorganize their power by working on local constituencies to defend and seize strategic positions of local governments [20].

Meanwhile, the decentralization regulation has had a major impact on the expansion of his power in Muna Regency. Decentralization policy has given the local authority to elected officials to organize and select local officials. As the informant's statement explained that the local boss's strategy of building political power in Muna was conducted by incorporating his cronies into the local bureaucracy structure and occupying strategic positions in local government structure. Looking at the results of the above interviews it can be said that Ridwan BAE tried to build its power base in organizing the government by placing the people in the government organizational structure in Muna Regency. It gave Ridwan BAE good position in controlling and mobilizing his interests in Muna Regency. Thus, all became a strategy in strengthening the power base and building a network of clientelism for its own interests and ambitions.

The victory of Ridwan BAE was indicated by a political conspiracy based on informant interviews as follows:

"Ridwan's victory is inseparable from the transactional process and the political deals with several DPRD members, especially in the Golkar faction and Ridwan's important people is La Iwipahuwa, Mbaliada, Ali Tanda, La Ode Sefu, and Kadir Ole".

When referring to the above statement, the inevitable political transactions and the implications of it greatly affect the actions of others. His capacity as a national politician and businessman made it easier to lobby and to click on some members of the DPRD in Muna Regency. Thus, after conducting political transactions the local boss performed a political click with some DPRD members together in a common interest. This shows the economic and material resources have the flexibility to gain power, to buy votes, to hire professional services for the sake of ambition and personal interests. By having those resources he can influence and determine the next election result, especially in a local election in 2006.

\subsection{Forming of Power Structure in Muna Government}

Sidel said that the presence of political decentralization, the expansion of the role of the state at the local level, the control of bureaucracy and the local economy have facilitated the emergence of local bosses within the powers of the state [21]. In the case of Muna Regency, local bosses played an important role in the changing political structure that took place in local politics. All cannot be separated from his role as a regent where the resource state was used as a basis of power and authority so widely in managing the region. This was due to changes in the laws listed in Law no. 22 and 25 of 1999 which provided the widest possible authority and power for the regents and mayors to organize and run the government in accordance with the meaning of autonomy itself.

It was supported by the nature of the state listed in the decentralization regulation has had a major impact on the expansion of Ridwan BAE's power in Muna Regency. He then formed a political force in Muna government by building his power structure which was started from 
within the bureaucratic structure of the region by including his cronies occupying strategic positions in government.

By building on the bases and knots of power in Muna government it had facilitated him in controlling of local bureaucrats. As in the literature, Mahyuddin considered that Ridwan BAE has great power to determine bureaucratic officials with political considerations and close relationships with criteria such as having a contribution to the political party and personal bonding relationship [22]. This shows that Ridwan BAE is trying to build a network of clientelism based on the special relationship formed from personal bonds. It may be a recruitment model that relies on a close relationship giving the local boss the easiness to mobilize his interests for his personal ambition.

Through such great power and influence, Ridwan BAE established his relationships with bureaucrats based on coercive powers. The nature of coercion sourced from the state power serves as a glue tool between Ridwan BAE and subordinates which sanctions and rewards are interpreted to create compliance for subordinates who then form loyalty to him. Also, placing top position as a bureaucratic boss who then forms an instrumental relationship in which sanctions become a glue tool for relationships between local bosses and subordinates.

Giving sanctions to subordinates was a way for bureaucrats to accept and obey in serving the interests of local bosses. Meanwhile, being a faithful follower was a key to the longevity of the bureaucrat's continuity in the government regime. Thus, it naturally formed a patronclient relationship where Ridwan BAE had great political resources while bureaucrats became loyal followers of local bosses. However, the relationship was shaped because of his ability to utilize the power and influence that rests on the state resource in which the coercive nature of the state was used as a glue tool of relationships between local bosses and regional bureaucrats.

\subsection{Popular Policy in Forestry Sector}

How does Ridwan BAE take over the management of the local economy in the forestry sector in Muna Regency? Then, what steps did Ridwan BAE take in control of the forestry sector? Decentralization policy and the enactment of regional autonomy were the gateways for regions throughout Indonesia that were de facto in their power to control the implementation of natural resource policies in their respective regions [2]. This momentum was the structure of opportunity for Ridwan BAE to reorganize its territory in Muna Regency. Although decentralization was a key to districts in forestry sector management, in fact, that the province of Southeast Sulawesi was still trying to intervene to control the forest resources located in Muna Region.

At that time, the seizure of economic resources occurred between the Southeast Sulawesi Province and Muna Regency in attracting profits in the forestry sector. The strengthening of regional authority since the implementation of decentralization and regional autonomy did not weaken the interest of Southeast Sulawesi Province to gain an advantage in the forestry sector in Muna Regency. Although regional autonomy has been present, in reality, the governor of Southeast Sulawesi Province still assumed that they have full rights in implementing policies in the management of the forestry sector in Muna Regency.

This referred to Law no. 22 of 1999 on local governance where the management of natural resources was still under the authority of the central government as the holder of authority over the management of natural forest resources. Meanwhile, decentralization and regional autonomy provided authority to provinces that claim to still have the authority and power over forest natural resources vvv

[23]. This referred to PP no. 25 of 2000 on the authority of the government and the authority of the province as an autonomous region in the implementation of licensing across 
regions/municipalities covered the utilization of forest product, flora, and fauna, plantation, and processing of forest products. This interpretation reinforced implicitly the perception of the Provincial government still had an interest in the management of the forestry sector in Muna Regency.

In addition, at that time the governor was still referring to government regulation no. 64 of 1957 which authorized the Governor to manage forest resources including the right of distribution of timber utilization permits to a businessman. Tojopers in his research viewed that this reason reinforces the interests of the province under the authority of the Governor through the Forestry Service which authorizes PD Perhutanda to exploit and marketing teak to be sold to the market under a marketing and selling system under the auction process [24]. While PD Perhutanda became a regional company that worked to manage wood raw materials that were directly responsible to the provincial.

Thus, it was clear that there was a confusion in the meaning of decentralization which had implications in the seizing power in the forestry sector. The most debatable issue was on who was worthy of managing the sector. This became an opportunity structure for Ridwan BAE to manage its territory in Muna Regency. Thus, with formal resources, state autonomy, and capacity as regents, Ridwan controlled the local economy through reorganizing the forestry sector in Muna Regency. All that was an effort to restore local economic control to Muna government. By that, he began to build a populist discourse on sector forestry policies that had previously contributed huge losses in the economic aspects of Muna Regency.

Quoting the report on Kendari Pos 2000, in a local boss interview explicitly explained that since the province had the authority in running the forest sector management policy, it only gave a big profit for Southeast Sulawesi Province. The forestry sector only gave benefits to the Muna Regency revenue (PAD) of 30\% while the Southeast Sulawesi Province got a $70 \%$ profit. According to Ridwan BAE, with the return of the authority of the Regional Government (second level government/TK II) of the Regency of Muna, local government revenue (PAD) can be even greater. In addition, the exploitation activities in Muna Regency impacted a great disadvantage for the region while teak forests were community-owned and not state-owned gardens.

In this regard, the local boss was building a discourse on forestry management in Muna Regency. The management of the forestry sector in increasing local government revenue (PAD) can be categorized as a symbol of "meaning" that it was not just information about development policies and programs. However, it had an interdependent relationship in economic and political interests. Borrowing Usman's (2015) argument that the discourse on forestry management in the social and historical dimension was strongly rooted in the economic and political interests The uncertainty of the forestry decentralization format was the motive of economic and political interests as a way to preserve power [25]. Therefore, through the development discourse, the impacts of various community responses, NGOs and community leaders who demanded to withdraw forestry management were returned under the authority of the Regency. Popular policy through the discourse of development was the ability of local bosses in influencing opinion and constructing people thought.

After the rolling populist policy, Ridwan BAE prepared strong regional boundaries between the provincial and district authorities in the management of the sector. Through regional regulation (Perda) No. 17 of 2000 concerning the autonomy of regional government with the Muna forestry agency becoming as the sole expert in teak forest management, Ridwan BAE had control over teak forest management. The establishment of the forestry agency would be directly responsible to the district head in a situation that allowed regulating all sector activities in Muna. In addition, Ridwan BAE had the power and authority to give 
permits and wood shipments to local companies and exited Muna Regency under the pretext of increasing regional prices.

Even so, the forest sector activities carried out by Muna Regency obtained from the Southeast Sulawesi Province. This can be seen from the issuance of the Decree of the Governor of Southeast Sulawesi Province No.522 / 64287 November 2001 concerning the prohibition of the shipment of teak out of Southeast Sulawesi Province. However, this did not stop the steps and interests of Ridwan BAE from carrying out the sale and delivery activities of logging. Consequently, relations between provinces and regencies in the era of decentralization had not gone so well. Normal, Ridwan BAE had succeeded in using limited resources to control natural resources. With the issuance of regional regulations and permits issuing Ridwan BAE, it had provided space for regional elites, politicians and businesses to compete to profit from the teak wood trading sector in Muna. This allowed its ability to construct networks and relationships in Muna Regency.

The policy of "regent instruction" in turn led to patronage and clientelism practices that would impact corruption and rent-seeking practices in the forest sector. In practice, patronage and clientelistic politics provided the advantage of draining resources in the forest sector. Indonesia Corruption Watch revealed that the timber auction policy had provided economic benefits to all stakeholders, district officials, police, DPRD and politicians where the timber auction procedures listed in the Bupati's Decree had regulated the basic price of timber sales and the provision of incentive funds to the auction committee which flows economic benefits to high officials to the lower levels.

Not only that, environmental and anti-corruption NGOs suspected that collusive practices and corruption had occurred in the implementation of policies in forestry management which were indicated by the irregularities in the implementation of the Muna Regional Budget from 2001 to 2007 which allegedly led to the economic interests of local bosses whose personal wealth surged sharply since in 2001. Based on data from FITRA and ICW, for example, there was corruption committed by local bosses, which reached at 11.6 billion, which was obtained from four sources of income, namely teak wood auction, replacement costs, reforestation funds and forest resource provision funds that brought losses. large in the country in 20022003[26].

3.5 Relations between Local Bosses and Politicians, Businessmen in The Forest Sector

At that time, Ridwan BAE re-established a new policy on the management of the trade system in the timber sector, especially the management of teak. It was undeniable that teak was a type of processed wood, which great economic value. When it entered 2002, the local boss re-established a new policy in the form of a regional government regulation on the management of the timber trade sector by issuing a Property Management Permit (IPKTM). The IPKTM regulation was established which targets the local community of teak wood owners. Providing concession permits was an attempt by local governments to provide opportunities for communities to carry out small-scale exploitation on their plantation lands. This was to encourage regional economic growth by involving community participation in the business of timber trade. In the eyes of the community, this IPKTM policy looked so populist. The management of the timber trade system in the forest sector was also rolled out by utilizing regional wealth sourced from teak forests which were the main commodities to encourage an increase in Regional Original Revenues through IPKTM permit fees. But, populist policies were present amid the illegal logging activities caused by the many policies issued by local bosses in Muna Regency.

The presence of the IPKTM policy also gave a great hope to the public to be directly involved in the management of the timber trading business that would be managed by the local 
government. This can be seen from a large number of people trying to access small-scale concession permits to the local government. Nonetheless, the IPKTM Regional Regulation was the provision of concession permits and small-scale exploitation that was intended for the community. However, in reality, it must go through a strict administrative procedure. In the process, the people who would take the permit must get a recommendation directly from Ridwan BAE as the regent. This procedural model was the pretext of the regional government to avoid the occurrence of irregularities but in addition, it would also facilitate the Muna government agency to conduct surveillance.

In that case, local businessmen and politicians worked as intermediaries for people who were trying to get access to get permission from the local government. Local businessmen or people who were not in the clientelism network must make a bribe by giving facilitation payments to facilitate the process of permitting and transporting undocumented timber where the money was enjoyed by KUPTD, KRPH, sub-district head, police, and the village chief. The emergence of these intermediaries was due to scarcity and limited public access to the authority of Muna Regency. Like the environmental NGO report as follows [27]:

"In 2002 there are no less than 100 Owned Land Utilization Permits awaiting the disposition of the Muna Regent. For this permit, the amount of wood processed by each owner of the Permit for Land Use, between 300 and 800 cubic meters. Again, of the many proposed Land Use Utilization Permits to local governments 90 percent on behalf of brokers/brokers".

IPKTM permit owners were people who had close ties with the regent, generally local businessmen, bureaucrats, and legislators who were accomplices of the authorities [28]. As revealed by Walhi's data, 55 IPKTM permits issued by the Muna Regency government was mostly held by IPKTM members, some of them were close members of the DPRD such as La Mbaliada. Politicians and contractors were known to be very close to the regent. The motive of the practice of granting IPKTM permits, the applicants must use the services of local politicians and entrepreneurs who were in the clientelism network. But in practice there was an agreement that was first; the permit in question must be in the name of the broker, secondly; timber that had IPKTM must be sold to brokers at a set price and if these two conditions cannot be fulfilled by the applicant, then, of course, IPKTM would not be issued. While profits for brokers would double which they would be single buyers by buying cheaper wood between Rp. 200,000 - Rp. 300,000 per cubic, then the wood was sold back to outside entrepreneurs at a higher price between 1.5 million - 1.7 million [28].

Besides, Regent's instructions No. 11 of 2001 concerning the Implementation of Exploitation of Teak Wood, Jungle and Utilization of Teak Stumps in Industrial Plantation Forests (HTI), Pine Thinning and Communal Logging of Illegal Timber in Forest, and Timber Areas Originating from Community-Owned Land was seen as "an exploitation order which was so manipulative of stems, wood and teak stumps throughout forest areas. The implication of this policy raised illegal logging practices carried out by special groups formed by local governments where the activities were carried out in an organized manner. Full control of local bosses in the forest sector, in turn, led to draining and exploitation practices in the forest governance sector. At this point, Ridwan BAE formed a patronage network with local communities and other local elites.

In this context, the essence of patronage had worked by providing services, services and economic benefits that were distributed into clientelism networks. Distribution of patronage sources can be seen in the provision of personal services into clientelism networks to be able to get access to IPKTM, while local politicians and businessmen would then benefit from the community who owned the land where the timber would be bought and resold to outside entrepreneurs as agreed beforehand. IPKTM brokers were the sole buyers of timber 
landowners who provide huge benefits to these actors. But on the contrary, the owners of timberland only get small results from the sale of their timber. This shows that the IPKTM brokers act as patrons for the people who own timberland, whereas Ridwan BAE becomes a patron for IPKTM brokers. Providing access to local politicians and entrepreneurs has formed a network between Ridwan BAE and businessmen and politicians. Momo's study showed that the issuance of permits for IKPTM concessions given to brokers (politicians and businessmen) had been agreed upon where the client would provide loyalty and provided political support in the election later [29]. Thus, the forest sector was only a political instrument to maintain power and reap economic benefits.

\section{Conclusion}

The result of this paper reinforces that the state becomes a major source of local boss power to build a network of power on the structure of government. While the management in the forestry sector becomes a political instrument over the interests of local actor that is the source of patronage that is exchanged into the network of clientelism. More clearly, the forestry sector becomes a field of interest for actors or groups within networks and power alliances within which interrelationship exists between local boss and other local actors. Some policies in forestry sector issued by Ridwan BAE had succeeded shaping patronage as a strategy in maintaining local power by distributing benefits to the forestry sector.

Local politics, Ridwan BAE, was a product of political change after the collapse of the New Order regime. The local boss phenomenon in Muna Regency actually explains the strong penetration of the country at the local level. The state at this point is not only a machine of power but also a resource base for local bosses which is then exchanged with other local actors. The power network of local bosses and other local actors is patterned in transactional patronage and clientelism relations which ultimately breeds loyalty and loyalty.

As a local boss, Ridwan BAE managed to build his patronage network and clients through forest governance. He has strong influence and control over the forestry service, key government agencies (SKPD Kabupaten Muna) who are politicians, councilors, and local entrepreneurs. This is clearly seen in various regulations and permits (Perda, IPKTM, and Bupati instructions) that are used as negotiation tools.

The state, particularly Muna district government, provides the legitimacy of coercive and discretionary power used by local boss and actor to control and manage the forestry sector in Muna Regency. The study of local bosses in Muna Regency is almost like local bosses in the Philippines where state power is destined for the interests of economic control and political power. The presence of local bosses in the realm of the country has shown the country does not look weak as a weak state, but on the contrary, the local government under the leadership of the local boss looks tougher as a strong state. This is because the local boss has normative resources and the capacity from the state to build a power base and network in order to reap personal interests.

In short, this paper generally concludes the two forms of power relation patterns between local bosses and local actors in the forestry sector, namely; the first form is that the local boss relation in the institutional is coercive. The second form is that the relationship between local actors and politicians- businessmen are intertwined in a political atmosphere. In the case of power relation, interests exchanged in economic and political realms are used to maintain the power of local bosses at the local level. 


\section{References}

[1] C. Lay, "Democratic Transition in Local Indonesia: An Overview of Ten Years Democracy.," J. Ilmu Sos. dan Ilmu Polit. 15(3), 207-219., 2012.

[2] J. McCarthy, "Dijual ke hilir: Merundingkan kembali kekuasaan publik atas alam di Kalimantan Tengah," Politik lokal di Indonesia. 2008.

[3] E. Erman, H. S. Nordholt, and G. van Klinken, "Deregulasi tata niaga timah dan pembuatan negara bayangan lokal," in Studi kasus Bangka. Politik lokal di Indonesia, 2008.

[4] S. Hidayat, S. Nordholt, and K. G. Van, "Shadow State? Bisnis dan Politik di Provinsi Banten," in Politik Lokal Di Indonesia, 2007.

[5] J. T. Sidel, "Bossism and democracy in the Philippines, Thailand and Indonesia: towards an alternative framework for the study of "local strongmen," in Politicising Democracy, London: Palgrave Macmillan, 2005, pp. 51-74.

[6] BPS, "Statistic Board of Indonesia Kabupaten Muna Dalam Angka 2011." 2001.

[7] BPS, "Statistic Board of Indonesia, Kabupaten Muna Dalam Angka 2014," 2014.

[8] J. S. Migdal, "Strong societies and weak states: state-society relations and state capabilities in the Third World," in Princeton University Press, 1988.

[9] J. T. Sidel, "Philippine politics in town, district, and province: Bossism in Cavite and Cebu,”. J. Asian Stud. 56(4), 947-966., 1997.

[10] M. Budiarjo, "Konsep Kekuasaan: Tinjauan Kepustakaan,” in Aneka Pemikiran Tentang Kuasa Dan Wibawa, Jakarta: Pustaka Sinar Harapan, 1991, p. 9.

[11] J. M. Kurian, G. T., \& Boryczka, "'Feminism.' and 'Radical Feminism.,", Encyclopedia of political science. CQ Press, 2010.

[12] S. Gunther, S. Harriss, and Tornquist, "Dapatkah Deliberasi Publik Mendemokratisasi Aksi Negara? Dewan Kesehatan Kotapraja Dan Demokrasi Lokal di Brazil,” in Politisasi Demokrasi: Politik Lokal Baru. Terj., Jakarta: Demos, 2005, p. 12.

[13] C. F. Andrain, Kehidupan Politik dan Perubahan Sosial, terj. Luqman Hakim. Yogyakarta: PT Tiara Wacana Yogya, 1992.

[14] D. W. Brinkerhoff and A. A. Goldsmith, "Clientelism, patrimonialism and democratic governance: An overview and framework for assessment and programming." USAID, Office for Democracy and Governance, 2002.

[15] E. Aspinall and M. Sukmajati, "Politik Uang di Indonesia: Patronase dan Klientelisme pada Pemilu Legislatif." Research Centre for Politics and Govern, 2015.

[16] K. R. Legg, "Tuan, Hamba dan Politisi”. Jakarta: Penerbit Sinar Harapan, . Hal 29.," 1983.

[17] W. C. MUller, "Patronase Partai Dan Kolonisasi Partai Atas Negara, dalam Richard S. Katz \& William Crotty.”Handbook Partai Politik”. Bandung, Nusamedia: . Hal 311.," 2014.

[18] D. R. Hancock and B. Algozzine, "Doing case study research: A practical guide for beginning researchers," Teachers College Press. 2016.

[19] E. Aryandi, "Bos Lokal di Way Kanan,Studi Kasus Kependudukan Lahan Register 42. Tesis.," Universitas Gajah Mada, (unpublished), 2011.

[20] H. S. Nordholt, "Decentralisation in Indonesia: less state, more democracy?. In Politicising Democracy (pp. 29-50). Palgrave Macmillan, London.," 2005.

[21] J. T. Sidel, "Bossism and democracy in the Philippines, Thailand and Indonesia: towards an alternative framework for the study of 'local strongmen'. In Politicising Democracy (pp. 51-74). Palgrave Macmillan, London.," 2005. 
[22] M. L. Ode., "Politisasi Pejabat Struktural (Studi Kasus Politisasi Pejabat Struktural Ekselon II di Sektretariat Daerah Kabupaten Muna Sulawesi Tenggara. Pascasarjana Administrasi Publik. Fakultas Ilmu Sosial dan Ilmu Politik. Uiversitas Gadjah.”

[23] I. G. Nurdjana and T. Prasetyo, "Korupsi dan illegal logging dalam sistem desentralisasi. Pustaka Pelajar.," 2005.

[24] L. O. Topojers, "Menebang Kayu Mengejar Rupiah Studi Etnografi Hutan Jati Muna". Program Studi Antropologi. Fakultas Ilmu Budaya Universitas Gadjah Mada. Yogyakarta. . Dissertation (unpublished).," 2012.

[25] S. Usman, "Esai-Esai Sosiologi Perubahan Sosial. Yogyakarta: Pustaka Pelajar.," 2015.

[26] Anti Korupsi, "Bupati Muna Korupsi Hasil Lelang Kayu Ilegal," Anti Korupsi. [Online]. Available: https://antikorupsi.org/id/content/bupati-muna-korupsi-hasillelang-kayu-ilegal-060804.

[27] FWI, "Eksploitasi Hutan Jati dengan IPKTM," Forest Watch Indonesia. [Online]. Available: http://fwi.or.id/eksploitasi-hutan-jati-dengan-ipktm/.

[28] M. A. Azhar, "Kerusakan Ekologis Hutan Jati Di Kabupaten Muna (Potret Pemujaan Pendekatan Anthroposentris)," J. Ilmu Sos. dan Ilmu Polit., vol. 11, no. 2, pp. 227 246, 2007.

[29] L. O. Hamrudin Momo, "Politik, Konflik Dan Kekerasan Terhadap Hutan di Kabupaten Muna”. Tesis.," Universitas Gadjah Mada Yogyakarta. . (unpublished), 2011. 